\title{
Genotyping of the EIF1AY Gene in Iranian Patients with Non-Obstructive Azoospermia
}

\author{
Elham Yarahmadia,b \\ Parnaz Borjian Boroujeni ${ }^{b}$ \\ Mehdi Totonchi ${ }^{\mathrm{b}, \mathrm{c}}$ \\ Hamid Gourabi ${ }^{b}$ \\ aJawaharlal Nehru Technological University, IST, Hyderabad, India; ${ }^{b}$ Department of Genetics, Reproductive Biomedicine Research Center, \\ Royan Institute for Reproductive Biomedicine; 'Department of Stem Cells and Developmental Biology, Cell Science Research Center, \\ Royan Institute for Stem Cell Biology and Technology, ACECR, Tehran, Iran
}

\section{Key Words}

EIF1AY gene • Azoospermia • Male infertility •

Polymorphism $\cdot$ Spermatocyte maturation arrest

\begin{abstract}
Background: EIF1AY is one of the genes essential for normal spermatogenesis and is located in azoospermic factors region. Objective: The present study was designed to investigate the EIF1AY gene nucleotide variations, and correlate it with spermatogenic maturation arrest and azoospermia in Iranian population. Methods: A total number of 30 Iranian idiopathic non-obstructive azoospermic patients were selected as case group and 30 fertile men served as a control group who had at least 1 child. Nucleotide variation was analyzed in exon 3 and exon 5 in EIF1AY gene of both groups. DNA extraction from peripheral blood samples of selected individuals was done followed by amplification by PCR and sequencing with Sangar method. Results: Totally 3 single nucleotide variations were identified: one in the intronic region of exon 3, next one in non-coding transcript exon variant (rs13447352) and the third one in the exonic region of exon 5, all were registered in NCBI-Gene database. Conclusion: There was no statistically significant difference in the incidence of nucleotide variation between 2 study populations ( $p>0.05$ ). Further studies are required to specify the effects of Y:T20588295G variation on modification of protein structure, as well as the expression pattern of the gene and its association with azoospermia.

(c) 2019 The Author(s)
\end{abstract}

Published by S. Karger AG, Basel

\section{KARGER}

Fax +4161306 1234

E-Mail karger@karger.com

www.karger.com
(C) 2019 The Author(s)

Published by S. Karger AG, Basel Open access

This article is licensed under the Creative Commons AttributionNonCommercial-NoDerivatives 4.0 International License (CC BYNC-ND) (http://www.karger.com/Services/OpenAccessLicense) Usage and distribution for commercial purposes as well as any distribution of modified material requires written permission.

\section{Introduction}

Infertility is a worldwide healthcare problem, which is defined as the inability to engender after 1 year of unprotected intercourse [1]. Studies have shown that $10-15 \%$ of couples suffer from infertility which male factor is co-responsible in half of them [2,3]. Genetic components and environmental factors are the 2 major reasons for male infertility [1]. Despite remarkable improvement in male infertility diagnostic methods, efforts are needed to unveil the causes of idiopathic abnormal spermatogenesis in about $50 \%$ of the population [4]. This condition could be associated with the mutations, polymorphism, or other changes in genes controlling spermatogenesis [5]. At the beginning of 1976, Tiepolo et al. [6] introduced the azoospermic factors (AZF) region on the long arm of the $\mathrm{Y}$ chromosome (Yq11.2) containing essential genes for spermatogenesis. Later Vogt et al. [7] defined 3 AZF regions of $\mathrm{Yq}(\mathrm{AZFa}, \mathrm{AZFb}, \mathrm{AZFc})$ which microdeletions in those could be responsible for azoospermia. Both Klinefelter's syndrome and AZF deletion have been shown as the main causes of spermatogenic failure [8]. Based on studies, about 5-10\% of severe oligospermic or azoospermic men have AZF microdeletions [9].

$\mathrm{AZFb}$ region is located almost between the subintervals $5 \mathrm{M}$ and $6 \mathrm{~B}$ [10]. Size of this region is $3.2 \mathrm{Mb}$ and encompasses several genes essential for normal spermatogenesis of which EIF1AY, PRY, TTY2, RBMY genes are the major candidate gene $[6,11]$. AZFb deletion in pa-
Hamid Gourabi

Department of Genetics, Reproductive

Biomedicine Research Center

Royan Institute for Reproductive Biomedicine

12 Hafez St, Banihashem St, Resalat St

PO Box 19395-4644, ACECR

Tehran (Iran)

E-Mailgourabi@royaninstitute.org 
Table 1. Sequences of oligonucleotide primers used for variation screening of $e I F 1 A Y$ gene

\begin{tabular}{|c|c|c|c|c|}
\hline Exon 3 & & & 0.96 & 399 \\
\hline Exon 5 & & & 0 & 586 \\
\hline Forward & ATCTTTCCTAAGCTGTTAATCAC & 58.21 & & \\
\hline Reverse & GTTGTCACTAAAGGAACTTTCAT & 57.28 & & \\
\hline
\end{tabular}

tients completely arrests the maturation process at spermatocyte stage [12]. Kleiman et al. [13] have shown that $A Z F$ gene in testicular biopsies of azoospermic men revealed lack of $E I F 1 A Y$ expression, can sporadically contribute to azoospermia.

Tian at al. [14] have shown lack of EIF $1 A Y$ expression may cause azoospermia in some cases. Vernet et al. $[15,16]$ have demonstrated that spermatogonial arrest in $\mathrm{XSxrbO}$ mouse males can be overcome by re-addition of $E I F 2 S 3 Y$ gene, and although there is no human copy of $E I F 2 S 3 Y$, EIF $2 S 3 Y$ gene is reported as equal to human EIF $1 A Y$ gene.

EIF $1 A Y$ is a 17,430 base pairs gene containing 7 exons, located on the non-recombining region of the Y chromosome (Yq11.223). It is also known as eIF4C [5]. It has been mapped to interval $5 q$ and subsequently defined between sY127-sY129 [17]. It encodes a protein related to eukaryotic translation initiation factor $1 \mathrm{~A}$ (eIF1A), which may function in stabilizing the binding of the initiator Met-tRNA to the 40S ribosomal subunit. eIF1A is one of the most conserved initiation factors and is essential for viability in yeast [18]. The EIF $1 A Y$ encodes a $\mathrm{Y}$ isoform of eIF1A, which aids the slippage of the $40 \mathrm{~S}$ subunit along the mRNA by indwelling the A site, which prevents possible interactions between tRNAs and mRNA that might fix the mRNA on the ribosome. eIF1A also enhances the formation of 5'-terminal complexes in the presence of other translation initiation factors.

EIFIAX gene is the homolog of EIFIAY with $86 \%$ identity, which encodes an essential eukaryotic translation initiation factor. The $\mathrm{X}$ homolog (eIF1AX) escapes inactivation in female [19] and both X and Y homologous are ubiquitously expressed with the high level of expression in the testis [20].

Although there is no AZF deletion in idiopathic patients, same features such as complete maturation arrest, have been observed. S1-like RNA-binding domain of the EIF1AY protein is necessary for translation initiation, and this domain of the protein is encoded by exon 2, 3, 4, and 5 of the gene. Based on the size of exons and RNA binding sites on conserved domain S1-IF1A, exon 3 and exon 5 were selected for studying the possible genetic changes in 30 non-obstructive azoospermic patients, referred to Royan Institute, Tehran, Iran.

\section{Materials and Methods}

Two groups of cases (patients) and controls were selected. Cases composed of 30 men with non-obstructive azoospermia, with normal karyotype, and no microdeletion in the AZF region. These patients had complete spermatogenesis arrest in spermatocyte stage. Control group composed of 30 fertile men who had at least 1 child. The mean age of patients and controls were 34.46 \pm 3.02 and $36.14 \pm 3.44$ years, respectively. There was no significant difference in ethnicity between the groups. Samples for control group prepared from volunteers and for cases from patients referred to Royan Infertility Clinic (Tehran, Iran) both after describing the aim of research and informed consent. The patient group demonstrated normal hormone level and none of the members was exposed to radiations, heat, chemotherapy, environmental hazards, and toxins such as pesticides, etc. throughout their life. According to the testicular sperm extraction diagnostic test of the department of pathology, no mature sperm was present in the testis samples of azoospermic patients.

Genomic DNA from peripheral blood was extracted using PAXgene Blood DNA kit (Qiagen, Germany) according to the manufacturer's protocol. The concentration and purity of isolated DNA were measured via NanoDrop Spectrophotometer 2000 (Thermo Scientific). Polymerase chain reaction (PCR) primers for exon 3 and partial of exon 5 were designed by Perlprimer v1.1.14 software (Owen Marshall) (table 1). Because of $86 \%$ nucleotide identity between $E I F 1 A Y$ gene and $I F I A X$ gene, selected primers sets were checked by primer BLAST software on NCBI site and UCSC Genome Browser Home (https://genome.ucsc.edu/). After confirming the specificity of primers on desired sites of $\mathrm{Y}$ chromosomes, designed primers were synthesized by Pishgam Company. PCR cycling protocol consisted of initial denaturation at 94 ${ }^{\circ} \mathrm{C}$ for 5 min, followed by 35 cycles of denaturation at $94^{\circ} \mathrm{C}$ for 45 $\mathrm{s}$, annealing at $57-58^{\circ} \mathrm{C}$ for $45 \mathrm{~s}$, extension at $72^{\circ} \mathrm{C}$ for $45 \mathrm{~s}$, and a final extension at $72^{\circ} \mathrm{C}$ for 5 min was set. PCR products were checked on $1 \%$ agarose gel. 
Table 2. Summary of polymorphisms present in 30 patients with complete maturation arrest and 30 fertile males

\begin{tabular}{llllllr}
\hline $\begin{array}{l}\text { Variant } \\
\text { number }\end{array}$ & $\begin{array}{l}\text { Change } \\
\text { zone }\end{array}$ & $\begin{array}{l}\text { Nucleotide variation in } \\
\text { chromosome position }\end{array}$ & $\begin{array}{l}\text { Polymorphism ID } \\
\text { in NCBI database }\end{array}$ & $\begin{array}{l}\text { Genotype } \\
\text { allele }\end{array}$ & $\begin{array}{l}\text { Allele frequency } \\
\text { in patients }(\mathrm{n}=30)\end{array}$ & $\begin{array}{l}\text { Allele frequency in } \\
\text { controls }(\mathrm{n}=30)\end{array}$ \\
\hline 1 & Exon-3 & Y:A20582781T & KT120030 & AA/AT/TT & $30 / 0 / 0$ & $27 / 0 / 3$ \\
2 & Exon-5 & Y:T20588295G & KT031067 & TT/TG/GG & $29 / 0 / 1$ & $30 / 0 / 0$ \\
3 & Exon-5 & Y:A20587967C & rs13447352 & AA/AC/CC & $19 / 0 / 11$ & $21 / 0 / 9$ \\
\hline
\end{tabular}

* Fisher's exact test was used.

The PCR products were sequenced using ABI 3730xl DNA Analyzer (Sequetech, Mountain View, CA, USA). Sequencing results were analyzed by Finch TV software (version1.4) and sequences aligned by Nucleotide BLAST at NCBI server for comparison with human EIF1AY gene sequence at the NCBI-Gene database.

\section{Statistical Analysis}

The obtained data were analyzed by statistical tools i.e. SPSS (SPSS, Chicago, IL version 15.0) software. To report qualitative variables, percentage and for measure variable quantitative, average and standard deviation were used. Depending on the number of counts Fisher's exact test and Pearson's Chi-square test were used for a comparative study between case and control groups. The $\mathrm{p}$ value of more than 0.05 was considered lack of association. Statistical results were calculated based on sequencing results.

\section{Results}

Exon 3 and its adjacent region, as well as partial of exon 5 of EIF1AY gene in 30 non-obstructive azoospermia men suffering from spermatogenesis maturation arrest, were successfully sequenced. The association between male infertility and genetic changes in EIFIAY gene were examined. Three nucleotide variations in the studied population identified, of which two were not previously reported to the NCBI database.

The sequencing results for exon 3 in control samples showed an intronic single nucleotide variation Y: A20582781T in 3 samples. The nucleotide variation observed in homozygous condition was registered on NCBI-Gene database with GenBank accession number KT120030. The frequency of this variation was $10 \%$ in the control group and $0 \%$ in the case group.

PCR product sequencing result for exon 5 of EIF1AY gene showed a single nucleotide variation in 9 control and 11 case samples. Nucleotide variation was located on exonic region Y: A20587967C, which was registered as noncoding transcript exon variant by rs13447352 in NCBI database. The frequency of this variation was $30 \%$ in the control group and 36\% in the case group.

In addition, another novel nucleotide variation located on Y: T20588295G in the exonic region of exon 5 was observed in only 1 case sample, which was registered at NCBI-Gene database as GenBank accession number KT031067.

Result from protein blast for nucleotide variation in exonic region Y: T20588295G showed alteration of alanine amino acid to glycine amino acid, both are small, non-polar amino acids and their aliphatic side chains do not allow any specific chemical interactions with other molecules.

Obtained $\mathrm{p}$ value for observed nucleotide variations in case and control groups showed no statistically significant difference in the incidence of polymorphism between 2 groups.

\section{Discussion}

Genetic changes in exon 3 and 5 of EIFIAY gene in idiopathic non-obstructive Iranian infertile patient with complete maturation arrest in spermatozoa were studied.

EIF $1 A Y$ gene is located on AZFb region on the $\mathrm{Y}$ chromosome, which encodes a protein initiating translation. Based on a study on XOSry transgenic male mouse for $E I F 2 S 3 Y$, this gene expresses in testis and is an important gene that drives spermatogenesis. It is reported EIF1AY gene, which is an analog of EIF2S3Y gene in human. The hurdle in the expression of EIF $1 A Y$ gene might sporadically contribute to azoospermia [13]. Hence, it was selected as a candidate gene in studying male infertility.

Pieces of evidence from the contribution of EIFIAY gene expression in sporadic male infertility [14] and spermatogenesis restoration in XSxrbO mouse males by 
re-addition of $E I F 2 S 3 Y$ gene which is a mouse homolog gene of EIF $1 A Y$, lead us to study this gene in our idiopathic azoospermia patients with maturation arrest $[15$, $16]$.

We identified one nucleotide variation in the intronic region of exon 3 (KT120030) that showed no statistically significant difference between the 2 groups. Indeed, genetic changes such as mutations in the intronic region have been shown to affect splicing and modify the function and structure of the protein. By checking the positions of the reported intronic variation, we noted that it was not located in splice site areas. Therefore, the hypothesis that this polymorphism is implicated in mRNA splicing of EIF1AY gene was not accepted.

Information about nucleotide variation rs 13447352 was entered as noncoding transcript exon variant, which is defined as a sequence variant that changes non-coding exon sequence in a non-coding transcript. It does not affect regulatory and motif features and also it is not clinically significant.
In this study, we demonstrated that nucleotide variation located on the exonic region of exon 5 (KT031067) caused alteration of alanine amino acid to glycine. Glycine is among the most mutated residues in all secondary structures and internal helical positions and it is more destabilizing than proline, while alanine is regarded as the most stabilizing residue [21]. Structural information of protein is required to understand the effects and consequences of the nucleotide variation on protein. Apparently, there is no connection between observed nucleotide variations and azoospermia.

\section{Acknowledgment}

We thank the study participants for their participation in this study. The authors would like to gratefully thank Dr. M. Lakshmi Narasu for her full support and Dr. A. Ghaheri for statistical analyses. This study was funded by a grant from the Royan Institute, Tehran, Iran (Grant number: 91000493).

\section{References}

1 Massart A, Lissens W, Tournaye H, Stouffs $\mathrm{K}$ : Genetic causes of spermatogenic failure. Asian J Androl 2012;14:40-48.

-2 Suganthi R, Vijesh VV, Vandana N, Benazir JF: Y Choromosomal microdeletion screening in the workup of male infertility and its current status in India. Int J Fertil Steril 2014; 7:253-266.

- 3 Attaman JA, Toth TL, Furtado J, Campos H, Hauser R, Chavarro JE: Dietary fat and semen quality among men attending a fertility clinic. Hum Reprod 2012;27:1466-1474.

4 Poongothai J, Gopenath TS, Manonayaki S: Genetics of human male infertility. Singapore Med J 2009;50:336-347.

-5 Jungwirth A, Giwercman A, Tournaye H, Diemer T, Kopa Z, Dohle G, Krausz C: European Association of Urology guidelines on male infertility: the 2012 update. Eur Urol 2012;62:324-332.

6 6 Tiepolo L, Zuffardi O: Localization of factors controlling spermatogenesis in the nonfluorescent portion of the human Y chromosome long arm. Hum Genet 1976;34:119-124.
7 Vogt PH, Edelmann A, Kirsch S, Henegariu O, Hirschmann P, Kiesewetter F, Köhn FM, Schill WB, Farah S, Ramos C, Hartmann M, Hartschuh W, Meschede D, Behre HM, Castel A, Nieschlag E, Weidner W, Gröne HJ, Jung A, Engel W, Haidl G: Human Y chromosome azoospermia factors (AZF) mapped to different subregions in Yq11. Hum Mol Genet 1996:5:933-943.

8 Plaseska-Karanfilska D, Noveski P, Plaseski $\mathrm{T}$ : Detection of the most common genetic causes of male infertility by quantitative fluorescent (QF)-PCR analysis; in Dijana Plaseska-Karanfilska (ed): Genetics of human diseases. Publisher InTech, 2011.

-9 ZhangYS, Dai RL, Wang RX,Zhang HG, Chen S, Liu RZ: Analysis of Y chromosome microdeletion in 1738 infertile men from northeastern China. Urology 2013;82:584-588.

10 Vogt PH: Report of the Third International WorkshoponHuman Y Chromosome Mapping 1997. Cytogenet Cell Genet 1997;79:1-20.
11 Shamsi MB, Kumar K, Dada R: Genetic and epigenetic factors: role in male infertility. Indian J Urol 2011;27:110-120.

12 Sadeghi-Nejad H, Farrokhi F: Genetics of azoospermia: current knowledge, clinical implications, and future directions. Part II: Y chromosome microdeletions. Urol J 2009; 4:192-206.

13 Kleiman SE, Yogev L, Hauser R, Botchan A, Maymon BB, Paz G, Yavetz H: Expression profile of AZF genes in testicular biopsies of azoospermic men. Hum Reprod 2007; 22:151-158.

-14 Tian Y, Stamova B, Jickling GC, Xu H, Liu D, Ander BP, Bushnell C, Zhan X, Turner RJ, Davis RR, Verro P, Pevec WC, Hedayati N, Dawson DL, Khoury J, Jauch EC, Pancioli A, Broderick JP, Sharp FR: Y chromosome gene expression in the blood of male patients with ischemic stroke compared with male controls. Gend Med 2012;9:68-75. 
15 Vernet N, Mahadevaiah SK, Ellis PJ, de Rooij DG, Burgoyne PS: Spermatid development in $\mathrm{XO}$ male mice with varying $\mathrm{Y}$ chromosome short-arm gene content: evidence for a Y gene controlling the initiation of sperm morphogenesis. Reproduction 2012;144:433-445.

16 Vernet N, Mahadevaiah SK, Ojarikre OA, Longepied G, Prosser HM, Bradley A, Mitchell MJ, Burgoyne PS: The Y-encoded gene Zfy2 acts to remove cells with unpaired chromosomes at the first meiotic metaphase in male mice. Curr Biol 2011;21:787-793.

17 Krausz C, McElreavey K, Weissenbach G, Forti G, Bishop C: Identification and mapping of a novel $\mathrm{Y}$ chromosome isoform of eIF-1A. Miniposter book, 10th European Workshop on Molecular and Cellular Endocrinology of the testis, 1998.
18 Battiste JL, Pestova TV, Hellen CU, Wagner G: The eIF1A solution structure reveals a large RNA-binding surface important for scanning function. Mol Cell 2000;5:109-119.

-19 Ross MT, Grafham DV, Coffey AJ, Scherer S, McLay K, Muzny D, Platzer M, Howell GR, Burrows C, Bird CP, Frankish A, Lovell FL, Howe KL, Ashurst JL, Fulton RS, Sudbrak R, Wen G, Jones MC, Hurles ME, Andrews TD, Scott CE, Searle S, Ramser J, Whittaker A, Deadman R, Carter NP, Hunt SE, Chen R, Cree A, Gunaratne P, Havlak P, Hodgson A, Metzker ML, Richards S, Scott G, Steffen D, Sodergren E, Wheeler DA, Worley KC, ect: The DNA sequence of the human X chromosome. Nature 2005;434:325-337.
20 Lahn BT, Page DC: Functional coherence of the human Y chromosome. Science 1997; 278:675-680.

21 Khan S, Vihinen M: Spectrum of diseasecausing mutations in protein secondary structures. BMC Structural Biol 2007;7:56. 